Vol. 1, No. 2, December 2020: p. 155-163 DOI: 10.18326/islah.vli2.155-163

ISSN : 2723-407X

Website: https://e-journal.iainsalatiga.ac.id/index.php/islah

\title{
Arabic Contribution toward Indonesian Vocabularies: Analysis of Q.S. Al-Baqarah
}

\section{Siti Isnaniah}

Institut Agama Islam Negeri (IAIN) Surakarta

sisnaniah7@gmail.com

\section{Tiya Agustina}

Pascasarjana Universitas Sebelas Maret

tivaagustina87@gmail.com

\section{Submission Track:}

Received: 31-08-2020

Final Revision: 01-03-2021

Available Online: 01-03-2021

\section{Abstract}

Arabic has a wide contribution toward Indonesian vocabularies, literary and commentary. This writing is aimed to describe the contribution of Arabic toward Indonesian vocabularies in Q.S. Al-Baqarah. The research uses qualitative descriptive method to describe the language forms in surah Al-Baqarah and their influences in Indonesian vocabularies. This research is a library research through content analysis techniques. The primary source of data is verses in Al-Qur'an Surah Al-Baqarah Verse 1 to 286, and the secondary source is Great Indonesian Dictionary Fifth Edition (Kamus Besar Bahasa Indonesia Edisi V/KBBI V). The result of the study shows that there are 52 Indonesian vocabularies come from Arabic; mostly the word "kitab" which appears 19 times, and the least ones are the words mutakin, gaib, rabi, akhir, mukmin, kulub, muslih, maut, lillahi, alim, khalifah, khusyuk, syafaat, furqan, tobat, mati, rahmat, jahiliah, mukmin, magrib, masjid, nikah, duafa, syahid which appear once (1); translation from Arabic to Indonesian in Surah Al-Baqarah is mostly literal translation so it causes a problem in the word "qulub" the plural form of "kalbu" (heart), based on Indonesian grammar, the word is written "kalbu". The letter "q" which is adapted from Arabic is written as " $\mathrm{k}$ " in Indonesian. People who understand Arabic will surely make it a problem because "kalbu" in Arabic (kaf, lam, ba') means dog. Meanwhile, "qalbu" (qaf, lam, ba') means heart. For this reason, the writing of the word "qolbu" or "qalbu" is still used by many people or media up to now.

\section{Key words: Arabic Contribution, Indonesian, Vocabulary.}


Arabic Contribution toward Indonesian Vocabularies.... (Siti Isnaniah \& Tiya Agustina)

\section{INTRODUCTION}

The dynamic development era affects the development of science and technology. Unexpectedly, there are so many changes in science, especially language. The science of language (linguistics) will always change and develop because it is dynamic. The developing language form is Indonesian. Being a multilingual country, Indonesia has many traditional language varieties. The numerous heterogenic people become the background of the variety. Besides, it also gives impact to the high mobility so people will tend to use two or more languages, completely or partly, in accordance to their needs. What happens nowadays is that the use of adapted foreign languages gives big impact to Indonesian vocabularies.

There are so many adapted words from foreign languages such as Arabic, English, as well as Malay, that they become familiar. Bakalla ${ }^{1}$ stated that the condition is influenced by many factors, namely close geographical location, power, and needs. The close geographical locations will cause the languages to influence each other, such as Thai, Indonesian, Malaysian, which are Malay family. The power factor can be seen from colonialism era, such as Netherland, Britain, and Japan, which had colonialized Indonesia for long time. Those countries have also influenced the development of Indonesian, for example the adaptation of Dutch and English into Indonesian. According to a research conducted by Jumariam ${ }^{2}$, there are 3.280 words adapted from Dutch, 1.610 words from English, and 131 words from Portuguese.

The need factor is influenced by modernization process in every field, such as the use of Arabic in prayer and greeting for Muslims around the world; and the use of English as international language. The developments make language obey the agreed law. It happens because of the lingual and cultural contacts which are called interference, integration, codeswitching, and code-mixing. There is another lingual part in the use of the language that causes grammatical deviations.

Being part of Malay family, Indonesian develops according to the speaker's thought. Saphir and Whorf stated that language will form the speaker's ways of thinking and behaving. All of what people do are influenced by the characteristics of the languages.

\footnotetext{
${ }^{1}$ Bakalla, M. . Pengantar Penelitian Studi Bahasa Arab, Terjemahan oleh Males Sutiasumarga. Jakarta: Hardjuna Dwitunggal. 1990.

${ }^{2}$ Jumaniar Almanar dan Alma E. (1996). Senarai Kata Serapan dalam Bahasa Indonesia. Jakarta: Depdikbud
} 
However, the speaker's cultural contact in certain area will influence the development of the language, and so will cultural contact of Indonesian with foreign countries.

Arabic is the foreign language which also influences the numbers of Indonesian vocabularies. As a country with Moslem majority, Arabic highly dominates many kinds of fields, especially religion. Nowadays, there are many Arabic terms or adapted expressions used by people to communicate, such as the words of salat, magrib, sabar, istiqamah, azan, syukur, hidayah, zuhud, tobat, kafir. In social politics, there are many concepts formed from adapted Arabic, such as hukum, hakim, mahkamah, amar, fasal, bab, ayat, adil, adab, makmur, rakyat, hikmah, wakil, musyawarah, mufakat. It also strengthens the concepts of Indonesian state administrations.

Arabic contribution in Indonesian vocabularies is also proven in some researches, for example research conducted by Soedarno (1992) found 2.336 vocabularies adapted from Arabic, John (in Ghazali, 1999:5) found 2.750 vocabularies, and Kamali (in Ghazali, 1999) who studied Kamus Umum Bahasa Indonesia found 2.178 vocabularies ${ }^{3}$.

Being main language in holy book Al-Qur'an, Arabic becomes the second language which must be learnt by Muslims. Moreover, Arabic is also used in hadiths and classic books as references in understanding Islamics. Instead of being language of religion, adaptation of Arabic has become cultural language. It can be seen from the use of adapted vocabularies in the field of social-politics, economics, and culture. The development of Indonesian vocabularies from Arabic starts from the translation of verses in Al-Qur'an. One of the surah in Al-Qur'an which gives addition to Indonesian vocabularies is Surah Al-Baqarah. The data were taken from Surah Al-Baqarah because it is the longest surah in Al-Qur'an. There are 286 verses in this surah which can give vocabulary treasury to Indonesian.

For that reason, it is needed to group kinds of Arabic adaptation which are used in many fields, especially in the verses of surah Al-Baqarah. But, before the adoption is adopted, it is needed to translate from Arabic to Indonesian. It is aimed to find the equivalent meanings between the source language and the target language. Al-Zarqani explained translation (tarjamah) as revealing meaning from certain language with other expressions from different

\footnotetext{
${ }^{3}$ Ibid.
} 
language by completing meaning and $\mathrm{aim}^{4}$. Qaththan added that translation is a process of revealing original dialogue or concerning the structure ${ }^{5}$.

Moeliono defined translation as an effort to process messages or language contents with equivalence according to the language receivers, in case of meanings and models. Generally, translation will never be same with the target language ${ }^{6}$. Meanwhile, Catford stated, "Translation is replacement of textual material in one language (SL) by equivalent textual material in another (TL)" ${ }^{, 7}$. Nida and Taber stated that translation consists of reproducing in the receptor language message, first in terms of meaning and secondly in terms of style. This definition focuses in message equivalency between texts which are translated in target language concerning to meaning and language styles.

Meanwhile, Wilss in 'The Science of Translation' explained that translation is a transfer process which is aimed to transform written text in source language (SL) to target language (TL) optimally, and needs understanding of syntaxes, semantics, and pragmatics, as well as the analytical process of target language (TL). From the definitions, it can be concluded that translation is a process of transferring meaning or messages from source language (SL) to target language (TL) by concerning to the equivalency of translation and result of translation.

Although many experts have different point of views, the differences complete the constructed theory. As there are many different point of views in translation, Zarqani divided translation into two kinds, they are harfiyyah or lirteral translation, that is translation which shows the similarities with the origin in case of structure or system. This kind of translation is the same with deciding words or synonym from surce language. Commentary or tafsirriyah translation is a translation which does not concern with similarities with the origin in case of structure and order, but it focuses mainly on the description of meaning and whole aim.

Mansyur and Kustiwan added that in literal/harfiyyah translation cannot be used in some verses in Al-Qur'an, especially when it can cause meaning deviation. On the other hand, they stated that commentary/ tafsirriyah translation is more acceptable because

${ }^{4}$ Al-Zarqani, M. 'Abd al-'Azhim. (1411). Manâhil al-'Irfân î 'Ulûm al-Qur’ân. Mesir: Mustafa al-Bab alHalabi wa Auladuh

${ }^{5}$ Al-Qaththan, M. K. (2000). Mabâhits î ‘Ulûm al-Qur’ân. Kairo: Maktabah Wahbah.

${ }^{6}$ Moeliono, A. M. (1989). Tata Bahasa Baku Bahasa Indonesia. Jakarta: Balai Pustaka.

${ }^{7}$ Catford, J. C. (1965). A Linguistic Theory of Translation. Oxford: Oxford University Press. 
substantially, translation is transferring messages or meanings from source language to target language ${ }^{8}$. So, meaning should not be changed and should be complete.

Meanwhile, Catford classified translation into two kinds, they are 1) Total translation. Total translation may be best deined as replacement of SL grammar and lexis equivalent TL grammar and lexis with consequential replacement of SL phonology/graphology by (non-equivalent) TL phonology/ graphology. 2) Restriced translation. By restricted translation we mean replacement of SL textual material by equivalent TL textual material, at only one level that is translation performed only at phonological or at the graphonological level, or at only one of the two levels of grammar and lexis ${ }^{9}$.

Based on the experts, it can be synthesized that translation can be classified into two kinds, they are literal and meaning translation, and then it is transferred spoken and written. In the process of transferring spoken or written, sometimes there are different meaning caused by different sounds. However, synonymy is needed between translated source language and agreed target language. The limited knowledge of speakers also influences the development of the language and not all Arabic vocabularies have been standardized in Great Indonesian Dictionary Fifth Edition (Kamus Besar Bahasa Indonesia Edisi V). This study aims to describe the contribution of Arabic in the vocabulary of Indonesian, especially in language development.

\section{METHODOLOGY}

This research used descriptive qualitative method by describing the form of language in surah Al-Baqarah and its effects in Indonesian vocabulary treasury. This research is a library research using content analysis technique. Content analysis is a technique used to construct inferences (replicable), and data validity by concerning to the context. The primary sources of data in this research are verses in Al-Qur' an Surah Al-Baqarah Verse 1 to 286, and the secondary source of data is Great Indonesian Dictionary Fifth Edition (Kamus Besar Bahasa Indonesia Edisi V/KBBI V). Meanwhile, collecting of data in this research is conducted in form of documentation and see and note. These techniques are conducted in order to document lingual data. Triangulation was used to test the validity. The triangulation is source and method triangulation which retests the validity of the data collected in different ways. While, the technique of data analysis used data codification, data classification, data tabulation, and data interpretation.

\footnotetext{
${ }^{8}$ Kustiwan, M. dan. (2002). alîl al-Kâtib wa alMutarjim. Jakarta: Moyo Segoro Agung.

${ }^{9}$ Catford, J. C. (1965). A Linguistic Theory of Translation. Oxford: Oxford University Press.
} 


\section{DISCUSSION}

The Indonesian vocabularies (KBBI V) adapted from Arabic in Surah Al-Baqarah are in the table below:

\begin{tabular}{|c|c|c|c|}
\hline No & Vocabulary & Verse & Meaning in Dictionary \\
\hline 1. & Kitab & $\begin{array}{l}2,44,53,78,79,85,87,101, \\
105,109,113,121,129,146, \\
158,174,176,177,213\end{array}$ & $\begin{array}{l}\text { Books, God's revelations } \\
\text { constructed in a }\end{array}$ \\
\hline 2. & Huda & $2,5,6$ & Guidance \\
\hline 3. & Mutakin & 2 & $\begin{array}{l}\text { God fearing people, pious } \\
\text { people }\end{array}$ \\
\hline 4. & Gaib & 3 & Unseen, hidden, not real \\
\hline 5. & Salat & $3,43,110,277$ & $\begin{array}{l}\text { A series of worship done by } \\
\text { Muslims based on certain order } \\
\text { according to Islamic rules and } \\
\text { law, started with } \\
\text { takbiratulihram and ended with } \\
\text { salam }\end{array}$ \\
\hline 6. & Akhirat & $4,86,114,130$ & afterlife; hereafter \\
\hline 7. & Rabi & 5 & My God (used in praying) \\
\hline 8. & Kafir & $\begin{array}{l}6,19,24,26,34,40,89,90, \\
98,104,191,217,250,264, \\
286\end{array}$ & $\begin{array}{l}\text { A group of people who do not } \\
\text { believe in Allah Swt. And His } \\
\text { messanger. }\end{array}$ \\
\hline 9. & Azab & $7,10,114,49,85,165,166$ & $\begin{array}{l}\text { God's punishment for humans } \\
\text { as a result of ignoring the rule } \\
\text { and disobeying the comment in } \\
\text { religion }\end{array}$ \\
\hline 10. & Ilah & 8,23 & Idol, something idolized \\
\hline 11. & Akhir & 8 & end; the last; next \\
\hline 12. & Mukmin & 8 & $\begin{array}{l}\text { People who believe in Allah } \\
\text { Swt. }\end{array}$ \\
\hline 13. & Allah & $9,10,15,17,19,20,20$ & $\begin{array}{l}\text { The God who must be } \\
\text { worshiped by believer. The One } \\
\text { who crears the world and } \\
\text { everything in it. }\end{array}$ \\
\hline 14. & Kulub & 10 & Heart (plural of kalbu) \\
\hline 15. & Ardi & 11,22 & Earth; land \\
\hline 16. & Muslih & 11 & People who bring goodness \\
\hline 17. & Maut & 19 & Death \\
\hline 18. & Lillahi & 22 & $\begin{array}{l}\text { For the sake of (because, for) } \\
\text { Allah }\end{array}$ \\
\hline 19. & Sidik & $23,31,94,111$ & Right, honest \\
\hline 20. & Jannah & 25,82 & Heaven, paradise \\
\hline & Rezeki & 25,60 & $\begin{array}{l}\text { Earning from God to fulfill } \\
\text { every day needs in forms of } \\
\text { foods, clothes, and shelters }\end{array}$ \\
\hline
\end{tabular}




\begin{tabular}{|c|c|c|c|}
\hline No & Vocabulary & Verse & Meaning in Dictionary \\
\hline 22. & Fasik & 26,99 & $\begin{array}{l}\text { People who disobey His orders } \\
\text { and ignore all His restrictions }\end{array}$ \\
\hline 23. & Alim & 29 & $\begin{array}{l}\text { Knowledgeable (especially in } \\
\text { Islamics) }\end{array}$ \\
\hline 24. & Khalifah & 30 & $\begin{array}{l}\text { Managers of earth after the } \\
\text { prophet of Muhammad saw. } \\
\text { passed away. They had to keep } \\
\text { the Islamic syariat (law) in state } \\
\text { administration }\end{array}$ \\
\hline 25. & Malaikat & $30,31,161,177$ & $\begin{array}{l}\text { Allah's creatures who always } \\
\text { obey and remember Him, } \\
\text { created from nur (light), have } \\
\text { certain duties from Allah }\end{array}$ \\
\hline & Hakim & $\begin{array}{l}32,129,209,220,228,240, \\
260\end{array}$ & $\begin{array}{l}\text { Someone who judge a case (in a } \\
\text { court); a judge }\end{array}$ \\
\hline 27. & Sujud & 34,125 & $\begin{array}{l}\text { A statement of obedience by } \\
\text { knee down and bow the head to } \\
\text { the floor or ground }\end{array}$ \\
\hline & Zalim & $\begin{array}{l}35,92,95,254,258,51,124 \\
193,229,246\end{array}$ & $\begin{array}{l}\text { People who do bad things so } \\
\text { they incur losses for themselves } \\
\text { and others }\end{array}$ \\
\hline 29. & Setan & $36,168,208,268,275$ & $\begin{array}{l}\text { Bad spirits (who always affect } \\
\text { humans to do bad things) }\end{array}$ \\
\hline & Zakat & $43,83,277$ & $\begin{array}{l}\text { Part of duties/obligations of } \\
\text { Muslims around the world to } \\
\text { share their treasures to those } \\
\text { who need or disable. }\end{array}$ \\
\hline & Sabar & $45,153,155$ & $\begin{array}{l}\text { Ability to control oneself from } \\
\text { doing bad things because of } \\
\text { facing temptation from God }\end{array}$ \\
\hline & Khusyuk & 45 & $\begin{array}{l}\text { Surrender sincerely, surely, } \\
\text { modesty }\end{array}$ \\
\hline 33. & Syafaat & 48 & $\begin{array}{l}\text { Forgiveness given by Allah } \\
\text { through angels/malaikat, } \\
\text { prophets, or selected pious } \\
\text { people, with Allah Swt's } \\
\text { permission to reduce someone's } \\
\text { punishment in afterlife. }\end{array}$ \\
\hline & Syukur & $52,56,185$ & Thanks to Allah \\
\hline & Furqan & 53 & Differentiator between right and \\
\hline & Tobat & 54 & $\begin{array}{l}\text { Consciously being wary of } \\
\text { what the one has been done and } \\
\text { promising to leave what have } \\
\text { been done because of Allah } \\
\text { Swt. }\end{array}$ \\
\hline & Mati & 56 & $\begin{array}{l}\text { Losing the spirit; tidak no } \\
\text { longer alive }\end{array}$ \\
\hline
\end{tabular}




\begin{tabular}{llll}
\hline No & Vocabulary & \multicolumn{1}{c}{ Verse } & \multicolumn{1}{c}{ Meaning in Dictionary } \\
\hline 38 & Saleh & $61,82,130$ & Obey and sincerely do worship \\
\hline 39. & Takwa & $63,66,179,183,194,197$, & $\begin{array}{l}\text { Keeping oneself from Allah } \\
\text { Swt's torment by doing worship } \\
\end{array}$ \\
& 241 & $\begin{array}{l}\text { sincerely that had been } \\
\text { preached to Muslims and trying } \\
\text { to avoid His restrictions }\end{array}$ \\
& & & \\
& &
\end{tabular}

\begin{tabular}{llll}
\hline 40. & Rahmat & 64 & $\begin{array}{l}\text { Grant (Allah Swt.); mercy } \\
\text { (Allah Swt.) }\end{array}$ \\
\hline 41. & Jahiliah & 67 & Foolishness \\
\hline 42. & Kiamat & $85,113,174,212$ & The awakening day after death
\end{tabular}
(all death creature will be alive to be judged for what they have done)

\begin{tabular}{|c|c|c|c|}
\hline 43. & Mukmin & 97 & $\begin{array}{l}\text { People who believe in Allah } \\
\text { Swt. }\end{array}$ \\
\hline 44. & Muslim & $132,133,136$ & People who embrace Islam \\
\hline 45. & Syahadat & $140,282,283$ & $\begin{array}{l}\text { Stating and believing in heart } \\
\text { and saying through spoken } \\
\text { words that Allah is the only } \\
\text { God to worship and believing } \\
\text { that Muhammad is Allah's } \\
\text { messanger }\end{array}$ \\
\hline 46. & Magrib & 142 & $\begin{array}{l}\text { Compulsory prayer done in } \\
\text { three rakaat at dawn until the } \\
\text { red light in the west fades }\end{array}$ \\
\hline 47. & Kiblat & $142,144,145$ & $\begin{array}{l}\text { Direction to Kakbah in Mecca } \\
\text { (in prayer) }\end{array}$ \\
\hline 48. & Syuhada & 143,282 & $\begin{array}{l}\text { People who die syahid (plural } \\
\text { form of syahid) }\end{array}$ \\
\hline & Masjid & 144 & $\begin{array}{l}\text { A house or a building for } \\
\text { Muslims to pray/worship }\end{array}$ \\
\hline & Nikah & 237 & $\begin{array}{l}\text { a relation of two persons, a } \\
\text { man and a woman, stated in } \\
\text { form of (akad) based on } \\
\text { religious rules and law }\end{array}$ \\
\hline & Duafa & 266 & $\begin{array}{l}\text { Weak/poor } \\
\text { (economically, etc) }\end{array}$ \\
\hline & Syahid & 282 & $\begin{array}{l}\text { People who die because of } \\
\text { defending the religion }\end{array}$ \\
\hline
\end{tabular}

\section{Table 1. Data Classification of Adapted Arabic Vocabularies in Al-Qur'an}

The table above showed that al-Quran has contributed to the Indonesian vocabularies, such as in al-Baqarah Chapters. The contribution is found in Q.S. Al-Baqarah in which 52 Indonesian vocabularies come from Arabic; the mostly found vocabulary is "kitab" which appears 19 times, while the least ones are mutakin, gaib, rabi, akhir, mukmin, kulub, muslih, maut, lillahi, alim, khalifah, khusyuk, syafaat, furqan, tobat, mati, rahmat, 
jahiliah, mukmin, magrib, masjid, nikah, duafa, syahid which each appears once (1); the translation of Arabic to Indonesian in Surah Al-Baqarah is mostly literal translation so it causes a problem in the word "kulub" the plural form of "kalbu" (heart), based on Indonesian grammar, the word is written "kalbu". The letter "q" which is adapted from Arabic is written as " $\mathrm{k}$ " in Indonesian. People who understand Arabic will surely make it a problem because "kalbu" in Arabic (kaf, lam, ba') means dog. Meanwhile, "qalbu" (qaf, lam, ba') means heart. For this reason, the writing of the word "qolbu" or "qalbu" is still used by many people or media up to now. Those problems should not be sharpened. The use of good and correct Indonesian is the mid-point to bridge the lingual problems. So, the word "kalbu" in the sentence "kalbu is the king of the body which will implies the deed" would not mean dog.

\section{CONCLUSION}

Arabic has large contribution to Indonesian vocabularies which mainly ware taken from the Quran as religious term which in turn become popular term. Although there are some accelaration in term of phonological and morphological aspects. This acceleration is in order to synchronize with Indonesian phoneme and morphological forms.

\section{REFERENCES}

Al-Qaththan, M. K. (2000). Mabâhits î 'Ulûm al-Qur'ân. Kairo: Maktabah Wahbah.

Al-Zarqani, M. 'Abd al-'Azhim. (1411). Manâhil al-'Irfân î 'Ulûm al-Qur'ân. Mesir: Mustafa al-Bab al-Halabi wa Auladuh.

Bakalla, M. . (1990). Pengantar Penelitian Studi Bahasa Arab, Terjemahan oleh Males Sutiasumarga. Jakarta: Hardjuna Dwitunggal.

Catford, J. C. (1965). A Linguistic Theory of Translation. Oxford: Oxford University Press.

Chaer, A. (2014). Linguistik Umum. Jakarta: PT Rineka Cipta.

Jumaniar Almanar dan Alma E. (1996). Senarai Kata Serapan dalam Bahasa Indonesia. Jakarta: Depdikbud.

Kustiwan, M. dan. (2002). alîl al-Kâtib wa alMutarjim. Jakarta: Moyo Segoro Agung. Majid, N. (1998). Bahasa Arab dan Perkembangan Indonesia Modern. Malang: YB3.

Moeliono, A. M. (1989). Tata Bahasa Baku Bahasa Indonesia. Jakarta: Balai Pustaka.

Nur, T. (2014). Sumbangan Bahasa Arab Terhadap Bahasa Indonesia dalam Perspektif Bahasa dan Budaya. Jurnal Humaniora, 26(2).

Nurbayan, Y. (2014). Pengaruh Struktur Bahasa Arab Terhadap Bahasa Indonesia dalam Terjemahan Al-Quran. Jurnal Arabiyat, 1(1). 